\title{
Structural Investigation of Pyribenzoxim Using X-ray Crystallography
}

\author{
Kwang-Hỵeon Liu, Sangkee Rhee, and Jeong-Han Kim*

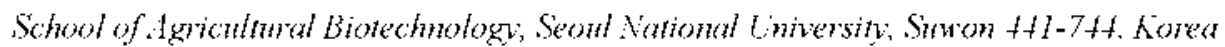 \\ Received Jome 10, 2002
}

Keywords : lrẹribenzoxim, Crvstallography, Herbicide.

\section{Introduction}

Pyriben/oxim, benzophenone $O-[2,6$-bis][4.6-dimethoxy2-py rimidiny l)oxy lbenzoylloxime (Figure 1), is a new postemergence herbicide developed by LG Chem Invesment (Korea). providing broad-speciruin weed control in rice Fields. ${ }^{1.2}$ As do the sulfony lurea and imidazolinone herbicides. this py rimidinyloxybenzoatc is known to inhibit acclolactatc Synthase (ALS), the en/yme involyed in the biosy nthesis of the branched anino acids in plants. "There was also no significant maternal or cubryonic toxicity. ${ }^{1}$ and no phytotoxicity was observed. 'The bioavailabilty was negligible in rats by the climination of radioaclivity with feces $(\sim 88 \%)$ and urinc $(\sim 8 \%)$ after 7 days of treatment. ${ }^{5}$ In the aquatic en ironment Sco et at suggested that the possibility of pyribenzoxim bioconcentration is not likely to occur. Since strictural details of pyribenroxim were nol yel known. knowing the related information could pave a way to designing more efficient and potent herbicidal compounds. For these reasons. in the present study the struclure of pyribenzoxim was delermined unambiguously with single crỵstal X-ray cỵ stallograplıy.

\section{Experimental Section}

Small crystals were obtained by slow cvaporation in a mixture of dichloromethane and hexane. The size of the data crystal is approximatcly $0.30 \times 0.20 \times 0.1+\mathrm{mm}^{3}$. Data colIection was performed with MoK $\alpha$ on an MXC3 Diffractomeler (Mac Science. Japan) cquipped wilh an incident beam graplite monochromator. The unil cell paramelers and the orientation matrix for data collection were oblained from the

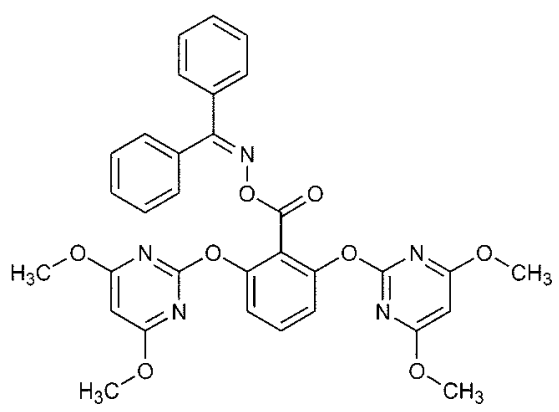

Figure 1. "The structural lomula of prribenzoxim.

"Correspondenee should be addressed: E-mail: kjh2404ta'snu.achr. Phonc: +82-31-290-2404, Fax: +82-31-293-8608 least-squares refinement using the setting angles of 15 reflections in the range $20^{\circ}<2 \theta\left(\mathrm{MoK} \alpha_{1}\right)<28^{\circ}$. The triclinic cell paramelers and calculated volumes are $a=10,+21$ (3) $\dot{A}$. $\mathrm{b}=12.555(4) \quad \mathrm{A}, \mathrm{c}=14.799(4) \quad \mathrm{A}, \alpha=100.32(2)^{\circ}, \beta=$ $106.00(2)^{\circ} . \gamma=110.96(2)^{\circ}$. and $1652.6(8) \dot{A}^{3}$. Intensity data were collected with the $\omega-2 \theta$ scan techniques. The intensitics of two standard reflections. showed no significant deviations during the data collection. A summary of the crystallographic data. data collection and structure refinement for the py ribenzoxim is given in Table 1 .

The centrosymmetric space group $P \bar{l}$ was assumed and the satisfactory refinement confinmed the choice of this space group. The initial position for all non hydrogen atoms were obtained by using direct methods of the SHELXS-86 program. The structure was refined by full matrix lcastsquares technique with the use of the SHELXL-93 pro-

Table 1. Crvistal data, data collection details and structure relinement results

\begin{tabular}{|c|c|}
\hline Chemical lormula & $\mathrm{C}_{32} \mathrm{II}_{2}-\mathrm{N}_{5} \mathrm{O}_{8} \mathrm{Cll}_{2} \mathrm{Cl}_{2}$ \\
\hline l'ormula weight & 694.51 \\
\hline lemperalure $(K)$ & $292(2)$ \\
\hline Wavelength $(\AA)$ & 0.71070 \\
\hline Crystal system & Triclinic \\
\hline Space group & PT $(+2)$ \\
\hline $\begin{array}{l}\text { Unit cell dimentions } \\
(a, b, c(\lambda), \alpha \beta, \chi("))\end{array}$ & $\begin{array}{l}.1-10.421(3) . b-12.555(4) \\
c-14.790(4) \\
\alpha-100.32(2), \beta-106.00(2) \\
\chi-110.96(2)\end{array}$ \\
\hline Volume $\left(A^{3}\right)$ & $1652.6(8)$ \\
\hline Z & 2 \\
\hline Density (calculated) (Mg m ') & 1.396 \\
\hline Absorption coctticient ( $\mathrm{mm}{ }^{\prime}$ ) & 0.256 \\
\hline$F(000)$ & 720 \\
\hline Crystal size (mm) & $0.30 \times 0.20 \times 0.14$ \\
\hline$\theta$ range for data collection (") & 1.51 to 25.00 \\
\hline Index ranges & $-12 \leq h \leq 0 .-13 \leq h \leq 14 .-16 \leq l \leq 17$ \\
\hline Reflections collected & 5848 \\
\hline Completeness to $2 \theta^{-25.00}\left({ }^{\circ} 0\right)$ & 93.9 \\
\hline Refinement method & Full-matrix lcast-squares on $F^{2}$ \\
\hline Datarestraints parameters & $5472: 0: 438$ \\
\hline Goodncss-of-tit on $F^{2}$ & 1.034 \\
\hline Final $\mathrm{R}$ indices $[1: 2 \sigma(I)]$ & $R_{1}-0.0379 . w R_{2}-0.0985$ \\
\hline $\mathrm{R}$ indices (all data) & $R_{1}-0.0460 . w R_{2}-0.1034$ \\
\hline Extinction coctticient & $0.013+(12)$ \\
\hline Largest diff. Peak and hole (c $\left.\AA^{3}\right)$ & 0.499 and 0.145 \\
\hline
\end{tabular}




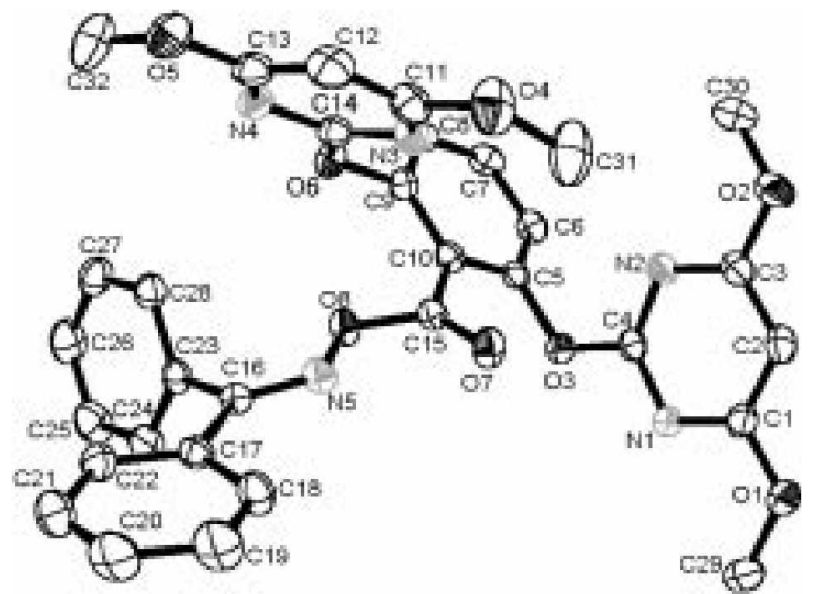

Figure 2. OR'liP diagram and numbering scheme for prribenzoxim.

gram. ${ }^{*}$ Anisotropic thernal motion for non-hydrogen atoms and extinction parameters were included. The final cycle of refinement performed on $\mathrm{Fo}^{2}$ with all 5848 unique reflections afforded residuals $m R_{-}=0.1034$ and the conventional $R$ index based on the reflections having $\left.\mathrm{Fo}>2 \mathrm{GFO}^{-}\right)$is 0.0379 .

\section{Results and Discussion}

An ORTEP diagram and numbering scheme for pyribenzoxim are shown in Figure 2. Two benzene rings of benzophenone oxime ester group of pyribenzoxim were nearly

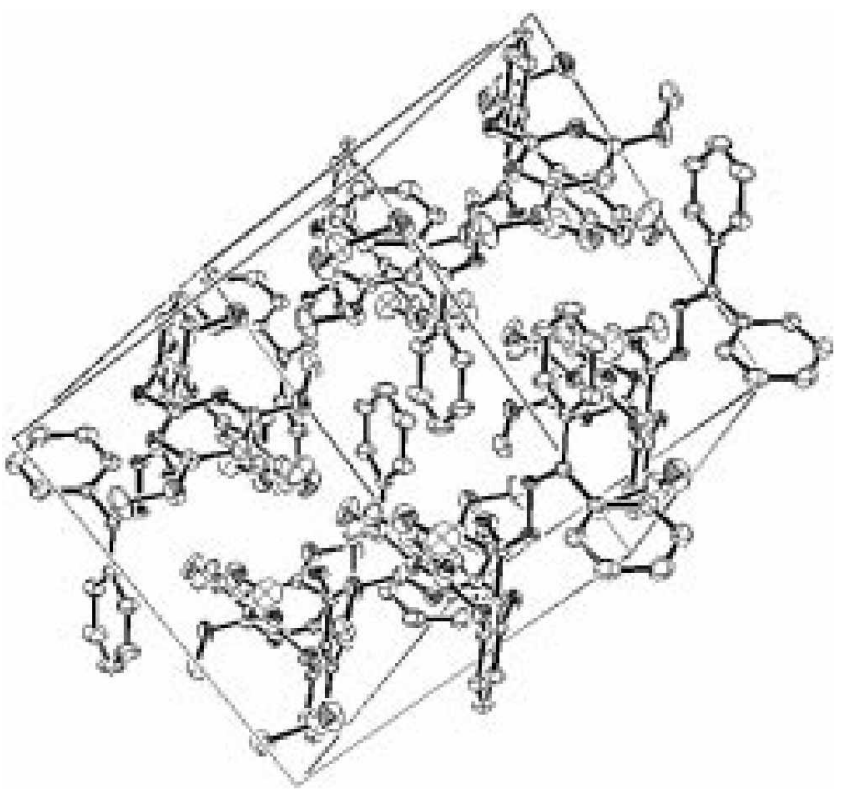

Figure 3. Packing diagram for pyribentroxim.

perpendicular to each other. Also, two dimethoxy py rimudine rings were not in the same plane. X-ray crystallography revealed that py ribenzoxim cocrystallizes with one molecule of dichloromethane. The mean C-C single bond length is $1.49 \mathrm{~A}$, in good agreement with the expected range for a $\mathrm{C}-\mathrm{C}$ single bond. Single bond length of nitrogen-oxygen and double bond length of carbon-oxygen are about 1.43 , and 1.20 A. respectively: Bond lengths among the phenyl ring

Table 2. Sclected bond lengths $(\Lambda)$, bond angles $\left({ }^{\circ}\right)$ and lorsion angles $\left({ }^{\circ}\right)$ for py ribenzoxim

\begin{tabular}{|c|c|c|c|c|c|}
\hline \multicolumn{2}{|c|}{ Bond (A) } & \multicolumn{2}{|c|}{ Angle $(\because)$} & \multicolumn{2}{|c|}{ Dihedral angle (c) } \\
\hline $\mathrm{C} \cdot \mathrm{l}-\mathrm{Nl}$ & $1.335(3)$ & $\mathrm{NI}-\mathrm{C} 1-\mathrm{O}) \mathrm{I}$ & $118.98(18)$ & $\mathrm{N} 1-\mathrm{C} 1-\mathrm{C}_{2}-\mathrm{C}_{3}$ & $-2.0(3)$ \\
\hline $\mathrm{C} \cdot \mathrm{l}-\mathrm{O}$ & $1.34+(2)$ & $\mathrm{N} 1-\mathrm{C} 1-\mathrm{C}_{2}$ & $123.96(18)$ & $\mathrm{Ol}-\mathrm{C} 1-\mathrm{C}^{2}-\mathrm{C}^{3}$ & $178.57(18)$ \\
\hline $\mathrm{C}^{3}-\mathrm{O}_{2}$ & $1.349(2)$ & $\mathrm{C} 3-\mathrm{C} 2 \mathrm{C} 1$ & $115.13(18)$ & $\mathrm{C} 1-\mathrm{C} 2-\mathrm{C} 3-\mathrm{O}) 2$ & $-177.11(18)$ \\
\hline $\mathrm{C}+4-\mathrm{Nl}$ & $1.329(2)$ & $\mathrm{N} 2-\mathrm{C} 4-\mathrm{Nl}$ & $129.17(17)$ & $\mathrm{O} 3-\mathrm{C} 5-\mathrm{C} 6-\mathrm{C} 7$ & $176.18(16)$ \\
\hline $\mathrm{C}+4-\mathrm{O} 3$ & $1.363(2)$ & $\mathrm{N} 2-\mathrm{C} 4-\mathrm{O} 3$ & $117.75(16)$ & C.7-(.8-C9-()6 & $-175.49(16)$ \\
\hline $\mathrm{C} 5-\mathrm{O} 3$ & $1.401(2)$ & $\mathrm{C} 6-\mathrm{C} 5-\mathrm{O} 3$ & $118.70(17)$ & $\mathrm{C} 6-\mathrm{C} 5-\mathrm{C} 10-\mathrm{C} 15$ & $-179.17(17)$ \\
\hline $\mathrm{C} 15-08$ & $1.370(2)$ & $\mathrm{C} 5-\mathrm{C} 10-\mathrm{C} 15$ & $119.85(16)$ & $\mathrm{O} 3-\mathrm{C} 5-\mathrm{ClO}-\mathrm{C} 15$ & $5.8(2)$ \\
\hline $\mathrm{C} 16-\mathrm{N5}$ & $1.287(2)$ & $\mathrm{O}-\mathrm{C}: 15-\mathrm{O} 8$ & $125.01(17)$ & $\mathrm{C} 5-\mathrm{C} 10-\mathrm{C} 15-\mathrm{O} 7$ & $39.9(3)$ \\
\hline $\mathrm{C} 29-\mathrm{Ol}$ & $1.439(3)$ & $\mathrm{O} 7-\mathrm{C} 1 \mathrm{5}-\mathrm{C} 10$ & $125.22(17)$ & $\mathrm{C} 9-\mathrm{C} 10-\mathrm{C} 15-\mathrm{O} 7$ & $-137.7(2)$ \\
\hline \multirow[t]{14}{*}{$\mathrm{C} 30, \mathrm{O}_{2}$} & $1.435(3)$ & N5-C $16-C 17$ & $115.42(16)$ & $\mathrm{C} 5-\mathrm{Cl} 10-\mathrm{Cl} 15-08$ & $-138.50(17)$ \\
\hline & & N5-C.16-C.23 & $125.86(16)$ & $\mathrm{C} 9-\mathrm{C} 10-\mathrm{C} 15-08$ & $43.9(2)$ \\
\hline & & $\mathrm{C} 16-\mathrm{N} 5-08$ & $110.33(14)$ & $\mathrm{N} 5-\mathrm{C} 16-\mathrm{Cl} 17-\mathrm{C} 18$ & $-13.0(3)$ \\
\hline & & $\mathrm{C} 4-03-\mathrm{C} 5$ & $116.27(14)$ & $\mathrm{C} 23-\mathrm{C} 16-\mathrm{C} 17-\mathrm{C} 18$ & $168.36(18)$ \\
\hline & & C.15-O8-N5 & $111.64(13)$ & $\mathrm{N5}-\mathrm{C} 16-\mathrm{C} 17-\mathrm{C} 22$ & $164.02(18)$ \\
\hline & & & & $\mathrm{C} 23-\mathrm{C} 16-\mathrm{C} 17-\mathrm{C} 22$ & $-14.6(3)$ \\
\hline & & & & $\mathrm{N} 5-\mathrm{C} 16-\mathrm{C} 23-\mathrm{C} 24$ & $114.1(2)$ \\
\hline & & & & $\mathrm{C} 17-\mathrm{C} 16-\mathrm{C} 23-\mathrm{C} 24$ & $-67.4(2)$ \\
\hline & & & & $\mathrm{N}_{2}-\mathrm{C} 4-\mathrm{O} 3-\mathrm{C}_{5}$ & $-10.7(2)$ \\
\hline & & & & $\mathrm{N} 1-\mathrm{C}+\mathrm{O} 3-\mathrm{C} 5$ & $170.02(15)$ \\
\hline & & & & $\mathrm{C} 6-\mathrm{C}^{5}-\mathrm{O} 3-\mathrm{C} 4$ & $92.0(2)$ \\
\hline & & & & $\mathrm{ClO}-\mathrm{C} 9-\mathrm{O} 6-\mathrm{Cl} 4$ & $67.3(2)$ \\
\hline & & & & O7-C.15-O8-N5 & $9.8(3)$ \\
\hline & & & & $\mathrm{ClO}-\mathrm{C} 15-08-\mathrm{N} 5$ & $-171.85(14)$ \\
\hline
\end{tabular}


Carbons are around $1.39 \mathrm{~A}$. in the expected range. Bond angles of $\mathrm{sp}^{2}$ ly brid of benzene ring are around $120^{\circ}$. The values of selected bond lengths, angles and torsion angles are given in Table 2. Figure 3 shows the packing mode of molecules in the unit cell. Two molecules of pyribenzoxim were packed with an inversion symmetry: The arrangement of the molecular units suggests that the packing should be stabilized by a network of intennolecular lydrophobic interactions between the benzene groups of beizophenone oxime groups of pyribenzoxim.

Acknowledgment. This work was supported by Korea Research Foundation Grant (KRF-2000-01.5-DP0286) to S.R. and BK2l project in part. Authors also thank to Solid State Chemistry Lab. of Ajou University (Prof. Hoseop Yun and Mr. Gangbeom Kim) for X-ray data analysis using $\mathrm{MXC} 3$ diffractometer.

\section{References}

1. Koo. S. I.: Ahn. S. C.: Lim. J. S.: Chae. S. H.: Kim. J. S.: Lee. I. H.: Cho. I. H. Isestic: Sci. 1997.51. 109 .

2. Koo. S. I.: Kim. J. S.: Lee. I. H. Kon J. Heed Sci. 1998. I8. 304.

3. Bae, Y. T.: Iee, I. II:- Koo. S. I. Kon J. Heed Sci. 1997, I7, (6).

4. Shin. H. C.: Shim. H. O.: Ahr. S. C.: Cho. J. H.: Chung. M. K.: Han. S. S.: Rol. J. K. J. Hhamacol. Exp. Ther 1998. 285. 795.

5. I.iu. K. I.: Moot, I. K.: Sung. II. I.: Kang. S. I.: Koo. S. I.: I .ee, I. S.: Kim. J. II. Pest Manag. Sci 2001. 57, 1155

6. Seo, J. S. I.iu. K. II.: Chung. K. I I. Shitn. J. S.: Kitm, I. H. Bull. Enwon. Contam. Toxicol, 2002.68.617.

7. Sheldrick. G. M. Acta Cristallogr: 1990. . +6.467.

8. Sheldrick. G. M. SHELWL-93. Progrom for the Refmement of

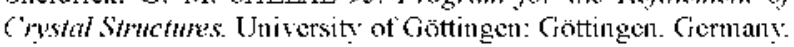
199.3 